ICIMOD

Case Studies on Flash Flood

Risk Management in

the Himalayas

In support of specific flash flood policies

\title{
(E) USAID
}

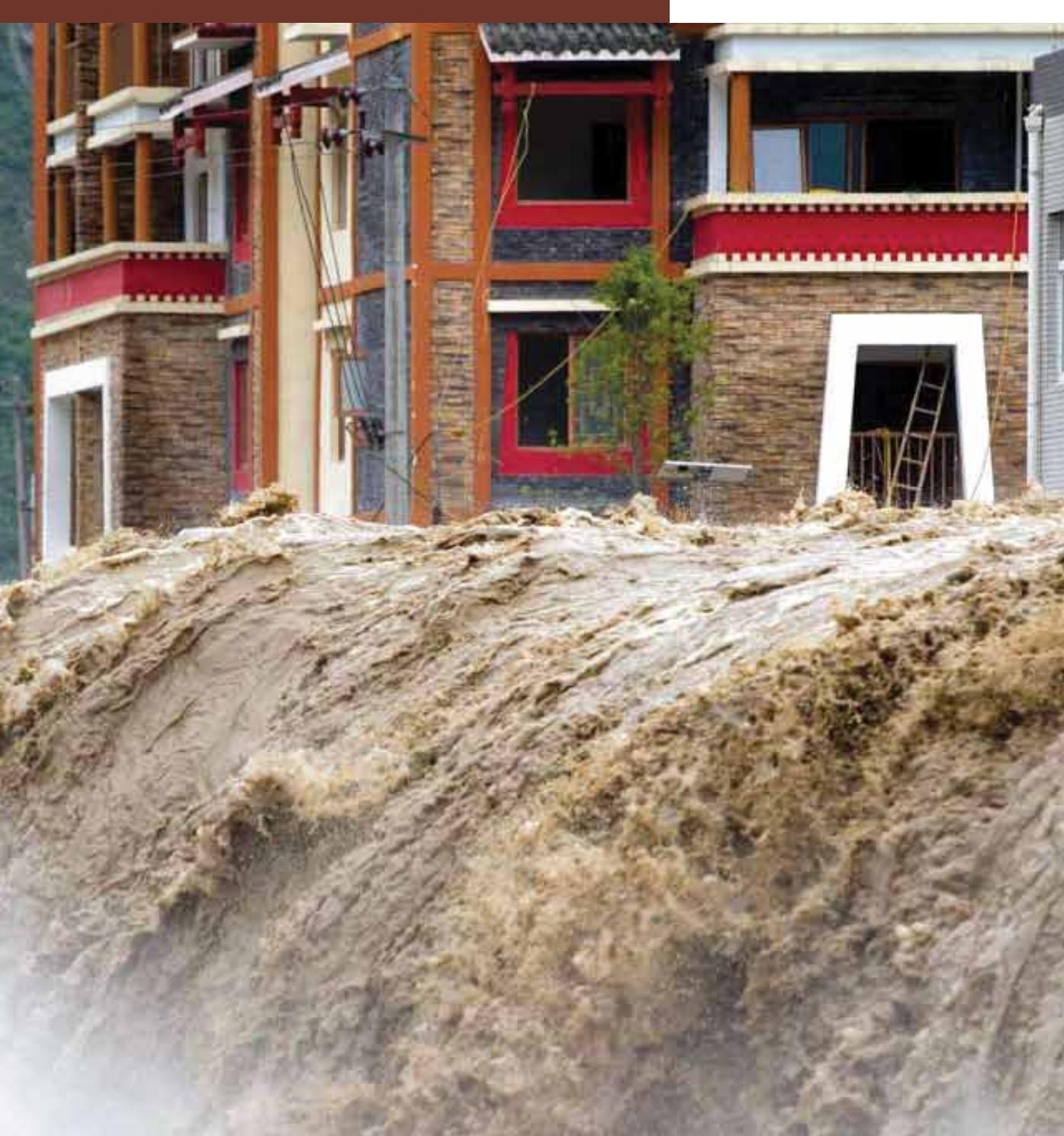




\section{About ICIMOD}

The International Centre for Integrated Mountain Development, ICIMOD, is a regional knowledge development and learning centre serving the eight regional member countries of the Hindu Kush Himalayas - Afghanistan, Bangladesh, Bhutan, China, India, Myanmar, Nepal, and Pakistan - and based in Kathmandu, Nepal. Globalization and climate change have an increasing influence on the stability of fragile mountain ecosystems and the livelihoods of mountain people. ICIMOD aims to assist mountain people to understand these changes, adapt to them, and make the most of new opportunities, while addressing upstream-downstream issues. We support regional transboundary programmes through partnership with regional partner institutions, facilitate the exchange of experience, and serve as a regional knowledge hub. We strengthen networking among regional and global centres of excellence. Overall, we are working to develop an economically and environmentally sound mountain ecosystem to improve the living standards of mountain populations and to sustain vital ecosystem services for the billions of people living downstream - now, and for the future.

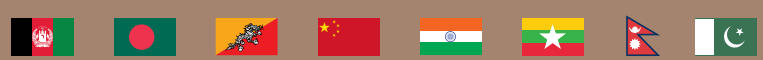

ICIMOD gratefully acknowledges the support of its core donors:

The Governments of Afghanistan, Austria, Bangladesh, Bhutan, China, India, Myanmar, Nepal, Norway, Pakistan, Switzerland, and the United Kingdom. 
Case Studies on Flash Flood

Risk Management in

the Himalayas

In support of specific flash flood policies

Editors

Arun B Shrestha

Sagar R Bajracharya 
Published by

International Centre for Integrated Mountain Development

GPO Box 3226, Kathmandu, Nepal

\section{Copyright (C) 2013}

International Centre for Integrated Mountain Development (ICIMOD)

All rights reserved. Published 2013

ISBN 9789291152698 (printed)

9789291152704 (electronic)

\section{LCCN 2013-310100}

Photos: Cover, pp 49, 51 - Prof. Yougshu Han

pp 20, 21 - Wali Mohammad Khan

pp 27, 28 - Partha J Das

pp 52, 53 - Sagar Ratna Bajracharya

\section{Printed and bound in Nepal by}

Hill Side Press (P) Ltd., Kathmandu, Nepal

\section{Production feam}

Andrea Perlis (Senior editor)

Susan Sellars Shrestha (Consultant editor)

Amy Sellmyer (Proofreader)

Dharma R Maharjan (Layout and design)

Punam Pradhan (Layout and design)

Asha Kaji Thaku (Editorial assistant)

\section{Note}

This publication may be reproduced in whole or in part and in any form for educational or non-profit purposes without special permission from the copyright holder, provided acknowledgement of the source is made. ICIMOD would appreciate receiving a copy of any publication that uses this publication as a source. No use of this publication may be made for resale or for any other commercial purpose whatsoever without prior permission in writing from ICIMOD.

The views and interpretations in this publication are those of the author(s). They are not attributable to ICIMOD and do not imply the expression of any opinion concerning the legal status of any country, territory, city or area of its authorities, or concerning the delimitation of its frontiers or boundaries, or the endorsement of any product.

This publication is available in electronic form at www.icimod.org/publications

Citation: Shrestha, AB; Bajracharya, SR (eds) (2013) Case studies on flash flood risk management in the Himalayas: In support of specific flash flood policies. Kathmandu: ICIMOD 


\section{Contents}

Foreword

Acknowledgements

\section{Part 1: Overview}

About This Study 2

Flash Flood Risk Management in the Hindu Kush Himalayan Region 3

Arun Bhakta Shrestha and Sagar Ratna Bajracharya

\section{Part 2: Case Studies for Regional Learning and Exchange}

Bhote Koshi/Sun Koshi River, Nepal: Potential GLOF risk assessment and management

Narendra Raj Khanal, Kamal Banskota, Arun Bhakta Shrestha, Pradeep Mool, and Chitra Prasad Acharya

Chitral, Pakistan: Flash flood risk assessment, capacity building, and awareness raising

Wali Mohammad Khan and Salman Uddin

Jiadhal River Catchment, Assam, India: Building community capacity for

flash flood risk management

Partha J Das

Lal Bakaiya Watershed, Nepal: Challenges and opportunities in flash flood risk management

Adarsha P Pokhrel, Narendra Raj Khanal, Khadananda Dulal, Rishi Rijal, Salikram Sigdel, Bijaya Raj Khanal,

Yadar Subedi, Chitra Acharya, Dhruba Thapa, and Bipin Acharya

Lumu Chimi Lake, Poiqu/Sun Koshi Basin, China and Nepal: Glacial lake outburst flood modelling

Pawan Kumar Ghimire and Bishwanand Misra

Madi River, Nepal: Landslide dam outburst flood risk management

Narendra Rai Khanal, Achyuta Koirala, Sher Bahadur Gurung, Umesh Kumar, Rishi Rijal, Salikram Sigdel,

Chitra Acharya, and Upendra Prasad Yadav

Niujuangou Gully, China: Flash flood monitoring and risk management

Yongshun Han and Arun Bhakta Shrestha

Xichang, China: Risk assessment and cartography of flash floods

Yongshun Han, Peng Huang, Longwei Li, Arun Bhakta Shrestha, and Sagar Ratna Bairacharya 



\section{Foreword}

A growing body of evidence indicates that the frequency and intensity of flash floods are increasing in the countries of the Hindu Kush Himalayan region. On 5 May 2012, a flash flood in Kaski, Nepal, killed at least 31 people, with many more unaccounted for. In Uttarakhand, India, 10 people lost their lives and 53 people went missing after a flash flood on 4 August 2012, and little more than a month later 33 people died and 35 people went missing from another flash flood on 15 September 2012. In Pakistan, 78 people were killed in a flash flood on 10 September 2012. These events call for the urgent attention of policy makers. This publication provides detailed evidence to help practitioners present the case for specific policies and action to manage flash flood risks.

Flash floods are severe flood events that occur with little or no warning. They can be triggered by intense rainfall, the outburst of a landslide dam lake, the failure of a natural or artificial dam, or a glacial lake outburst. The frequent occurrence of flash floods in the Hindu Kush Himalayan region poses a severe threat to lives, livelihoods, and infrastructure, both in the mountains and downstream. Vulnerable groups such as the poor, women, children, the elderly, and people with disabilities are often hardest hit. Flash floods tend to carry with them much higher amounts of debris than normal floods and as a result cause more damage to hydropower stations, roads, bridges, buildings, and other infrastructure.

Since its establishment in 1983, ICIMOD has explored different ways to reduce the risk posed by natural disasters and the physical and social vulnerability of the people in the region. Approaches have included training courses, hazard mapping, and vulnerability assessments, as well as fostering dialogue among stakeholders and developing materials for capacity building.

ICIMOD, in collaboration with various partners, has compiled and published resource materials on flash flood risk management to support capacity development and especially the training of planners and practitioners. As part of these efforts, ICIMOD published a set of resource manuals on flash flood risk management through communitybased management covering structural and non-structural measures. Based on these materials, ICIMOD has also recently published a training of trainers manual.

The case studies in this publication provide evidence to help practitioners influence policy and decision makers in ICIMOD's regional member countries. The studies provide evidence in support of a number of recommendations - above all that the countries of the region should develop policies and strategies specific to flash flood risk management, integrate flash flood management in watershed and water resource management, improve preparedness at all levels, and promote effective early warning systems. They should also empower communities to play a central role in flash flood management and collaborate with other countries for transboundary management of flash floods. The studies also demonstrate the need for institutional strengthening, flash flood modelling and hazard mapping, and the development and implementation of land use guidelines and building codes. Furthermore, countries should strengthen national networks of hydrological and meteorological observation and document flash flood events in a systematic way to enhance understanding.

This publication has been produced as part of the project 'Flash Flood Risk Reduction - Strengthening Capacity in the Hindu Kush Himalayas', supported by the United States Agency for International Development, Office for Foreign Disaster Assistance (USAID/OFDA). We hope that it will contribute towards developing effective strategies and policies and ultimately to reducing disaster risk and providing greater security for the people of this vulnerable region.

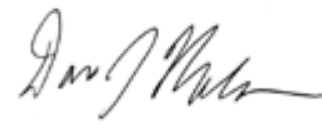

David Molden

Director General, ICIMOD 


\section{Acknowledgements}

This publication is an output of the project 'Flash Flood Risk Reduction - Strengthening Capacity in the Hindu Kush Himalayas', which was supported by the United States Agency for International Development, Office for Foreign Disaster Assistance (USAID/OFDA). Special thanks go to Sezin Tokar and Liza Mantilla of USAID/OFDA for their support to the project.

We would like to express our heartfelt thanks to the authors of the chapters for their hard work and keeping to deadlines. We are grateful to the many ICIMOD colleagues who reviewed the manuscript and provided constructive comments. We are grateful to Professor Hua Ouyang, then Programme Manager for Integrated Water and Hazard Management, for seeing the work through to completion, and to all the staff in this programme who supported its preparation.

Comments and suggestions from two external reviewers, Dr Juerg Merz, HELVETAS Swiss Intercooperation Nepal, and Dr KJ Anandha Kumar, National Institute of Disaster Management, Ministry of Home Affairs, Government of India, greatly helped to improve the document.

Warm thanks go to Susan Sellars-Shrestha (consultant editor) for bringing the manuscript to its present form. Thanks also to the editorial team of Andrea Perlis, senior editor, and Amy Sellmyer, proofreader, for their helpful insights. Heartfelt thanks to Dharma Ratna Maharian and Punam Pradhan for their hard work in laying out the manuscript in a very short time and to Asha Kaii Thaku for his editorial assistance.

\section{Acronyms and Abbreviations}

CERT Community Emergency Response Team

DEM digital elevation model

FOCUS Focus Humanitarian Assistance

GIS geographic information system

GLOF glacial lake outburst flood

HEC-RAS Hydrologic Engineering Center-River Analysis System

$\mathrm{HKH} \quad$ Hindu Kush Himalayas

LDOF landslide dam outburst flood

NAPA National Adaptation Programme of Action

NGO non-governmental organization

RS remote sensing

VDC village development committee 